\title{
Simulating Firm-Specific Corporate Marginal Tax Rates in a Canadian Context
}

\author{
Amin Mawani \\ York University, Toronto, Canada
}

This paper illustrates a methodology for estimating corporate marginal tax rates in the presence of tax losses, and within the context of Canadian tax law (JEL: G3, H25, M4).

Keywords: taxation; marginal tax rates; tax losses; corporate tax rates.

\section{Introduction and Motivation}

Researchers attempting to study the effect that tax laws have on corporate behavior often wish to measure a company's marginal tax rate, which is the present value of extra tax savings (liability) when taxable income decreases (increases) by $\$ 1$. Following Shevlin (1990), the marginal tax rate in Canada generally takes one of four forms: (1) the statutory tax rate in the current year (if the company is currently taxpaying); (2) the statutory tax rate in one of the past three years (if the company is incurring noncapital losses but has sufficient taxable income in the three-year carry-back period to be able to deduct them in computing taxable income for those past years and thus obtain an immediate refund); (3) the discounted value of the statutory tax rate in one of the next seven years (if the company has exhausted carry-back possibilities but is expected to have enough taxable income in the seven-year carry-forward period to deduct them in those years); and (4) zero (if the company does not have enough taxable income in either the carry-back or carry-forward periods to deduct these losses). In the presence of uncertainty, the marginal tax rate may be a weighted average

\footnotetext{
* I would like to thank Alan Macnaughton, Terry Shevlin, John Graham, Kenneth Klassen and Hussein Warsame for their guidance and helpful comments. Financial support from the Social Sciences and Humanities Research Council is gratefully acknowledged.
}

(Multinational Finance Journal, 2007, vol. 11, no. 1/2, pp. 77-96)

(C) Multinational Finance Society, a nonprofit corporation. All rights reserved.

DOI: $10.17578 / 11-1 / 2-3$ 
of these four possibilities. ${ }^{1}$

Forms (2) through (4) above are only relevant for firms with noncapital losses (the U.S. equivalent of net operating losses, or NOLs). Noncapital losses are quite common in Canada, and probably more common than in the U.S. ${ }^{2}$ The latest available information, which is for Quebec corporations, is that 59\% of all firms in 1992 had noncapital losses and thus may have a marginal tax rate other than the current statutory tax rate (Gouvernement du Québec Ministère des Finances [1997]). The latest Canada-wide figure, which is from 1985, is also 59\% (Glenday and Mintz [1991]), and in each year during the 1965 - 1985 period, at least $45 \%$ of corporations reported zero taxable income or a loss (Report of the Technical Committee on Business Taxation [1998]). This pattern is not limited to small corporations; during the 1977 to 1982 period, over $40 \%$ of investment was done by corporations that were rarely taxpaying, and a further $30 \%$ was undertaken by corporations that were taxpaying about half the time (Department of Finance, Canada [1985b], p17). It is also not limited to companies with book losses; in $1987,29 \%$ of all corporations which were not currently taxpaying were showing book profits (Holland and Castonguay [1992]), and 28\% of all profitable corporations did not pay federal corporate income taxes in 1994 (Chevreau [1998]). Some evidence that this pattern is continuing is that the cumulative amount of unused tax losses of corporations has grown from $\$ 35.6$ billion in 1985 to $\$ 87.5$ billion in 1993 (Report of the Technical Committee on Business Taxation [1998]), and more than doubled in the four-year period 1989- 1993 (Statistics Canada [1997]). ${ }^{3}$

Even though noncapital losses are common, the fact that statutory corporate tax rates in Canada have been relatively stable in recent years means that marginal tax rates might vary little from statutory tax rates if most tax-loss firms were in form (2) above (i.e., utilizing loss carrybacks at the margin). However, significant cumulative losses can take a

1. Although one might expect interest on this refund since it relates to a prior taxation year, paragraph 164(5)(d) of the Canadian Income Tax Act specifies that no interest is to be paid.

2. 30 percent of firm-years in the late 1980s in the U.S. were loss years (Hayn, [1995]). However, this may be understated to the extent that "many firms do not report the existence of NOL carry-forwards in their financial statements until they are nearing expiration", (Dhaliwal, Trezevant and Wang [1992], p17).

3. As these statistics suggest, measures of corporate taxes paid have an important public policy element that is often used in justifying greater political scrutiny (e.g., the Canadian banking industry's capital tax). Callihan (1994) and Zimmerman (1983) discuss the tax policy implications of corporate effective tax rates. 
long time to be used up; for example, only 15\% ( $\$ 13$ billion) of cumulative loss carry-forwards at the end of 1993 (\$87.5 billion) were applied to reduce taxable income of corporations in 1994 (Report of the Technical Committee on Business Taxation, [1998]). In addition, Mintz (1988) found that only $2 \%$ to $12 \%$ of present-value-weighted losses were carried back in 1979 to 1981 , so in that period at least $80 \%$ or more of loss firms would have been forced to carry forward the losses and therefore suffer the loss of present value (form (3)) or the inability to use the losses at all (form (4)).

Observed variations in marginal tax rates at the industry level suggest the magnitude of the variation across firms. In the years 1993 and 1994, average federal tax rates ranged from $6 \%$ in the mining industry to $26 \%$ in public utilities and deposit-taking institutions (Report of the Technical Committee on Business Taxation [1998]). Although this might suggest that industry-level marginal tax rates could proxy for the desired firm specific rates, there is too much variation within industries for this to be meaningful. Even within the resource industry, with an average marginal tax rate of $2 \%, 45 \%$ of investment was undertaken by taxpaying firms (Mintz [1991]).

All of this suggests that firm-specific marginal tax rates are needed. U.S. researchers have developed a methodology to estimate such rates from financial statement information (Shevlin [1990]; Matsunaga, Shevlin and Shores [1992]; Clinch and Shibano [1996]; Graham [1996a]; Boatsman and Gupta [1996]; and Graham and Smith [1999]). The objective of this paper is to suggest some refinements to the U.S. method, to show how this methodology may be applied to Canadian data, and to discuss the issues that arise in the Canadian context because of differences in the Canadian economic structure and Canadian tax rules.

This firm-specific simulated marginal tax rate is heavily dependent on data that is not readily disclosed in the public domain. As a result, its utility is likely to be evident for managers inside a firm that can retrieve all of the input parameters and verify the output decisions for their validity and relevance. Similar to Graham (1996a), the simulated marginal tax rate developed in this study is compared to other measures of firms' taxpaying status. The lack of perfect correlation across the different tax proxies suggests potential room for improvement in empirical studies using Canadian data and Canadian tax proxies. Using an inappropriate measure to proxy for firms' taxpaying status can result in biased and inefficient estimators since alternate measures may spuriously overstate or understate the marginal tax rate.

As confirmed by Shanker (1997), "a literature review suggests that 
there is no research on proxies for the marginal tax rates of Canadian firms" (p.199). While a wide range of measures have been used to proxy for the MTR rate in Canadian studies, only Mawani (1995) has used the simulated measure developed in this study. Mawani (2003), Klassen and Mawani (2000) and Shanker (1997), for example, rely on Graham's (1996a) trichotomous variable as a proxy for MTR. Warsame and Thornton (1998) use an unlevered tax rate "whereby tax expense is divided by net income before taxes, adjusted for both debt and investment-related tax shields" (p.18). Archambault and Archambault (1994) use average tax rates, while Day and Devlin (1994) use statutory tax rates to proxy for marginal tax rates. Shum (1996) acknowledges that actual taxes paid by firms is a censored variable, and therefore estimates a latent (taxes paid) variable as a function of the following exogenous variables: operating income, interest expense, book value of depreciation and amortization, the loss carry-forward benefit realized in the current year, and eleven industry dummy variables. In their study commissioned by the Technical Committee on Business Taxation, McKenzie, Mansour and Brule (1998) illustrate their calculation of marginal effective tax rates (METR), which they define as the amount of incremental tax arising from the decision to undertake one more unit of an economic activity (i.e., incremental unit of capital, incremental worker, or incremental unit of output).

\section{The Simulation Algorithm and Canadian Concerns}

The approach used by Shevlin (1990), and on which this paper is based, consists of four steps. The analysis below suggests improvements in steps 1 and 3. Problems with step 2 concerning banking of deductions and credits are discussed. Problems with step 4 concerning multinational corporations and corporate groups are also noted.

Step 1: The first step is to estimate taxable income before deducting loss carry-forwards and carry-backs for the current year and several past years using the following equation (which has also been used by Omer, Molloy and Ziebart [1991]),

$$
T I B L=N I B T-\frac{\Delta D T}{s t r}
$$

where $T I B L$ is taxable income before deducting loss carry-forwards and 
carry-backs, NIBT is net income before taxes for financial accounting purposes, $D T$ is deferred tax liability, and str is the statutory tax rate. The problem with this approach is its treatment of permanent differences between financial accounting and tax accounting. To see this, note that for most corporations, the difference between Net Income Before Taxes on their financial statements and Taxable Income Before Losses on their corporate tax return consists of Permanent Differences $(P D)$, Timing Differences $(T D)$, and Large Corporations Tax $(l c t)$. This can be expressed as: ${ }^{4,5}$

$$
T I B L=N I B T-P D-T D-l c t
$$

Since it is not disclosed separately by most firms, the timing difference $(T D)$ can be estimated by grossing up the change in deferred tax liability (or expense) over the previous year by the statutory tax rate (str), or:

$$
T D=\frac{\Delta D T}{s t r}
$$

Thus, by substituting (3) into (2), we have:

$$
T I B L=N I B T-P D-\frac{\Delta D T}{s t r}-l c t
$$

By comparing equation (4) with equation (1), it is apparent that Shevlin's approach neglects permanent differences and the Large Corporations Tax. Shevlin's estimate of taxable income is biased upwards to the extent that the sum of permanent differences and Large Corporations Tax is positive.

4. Permanent differences arise when revenues or expenses enters the computation of either taxable income or pre-tax accounting income, but never enters into the computation of the other. For example, dividend income is a permanent difference since Canadian corporations are not subject to taxation on dividends from Canadian sources. Other examples of permanent differences can be found in Beechy and Conrod (2003).

5. The lct is based on a corporation's capital base, and is largely independent of NIBT. The $l c t$ is neither a timing difference nor a permanent difference. It constitutes extra taxes paid regardless of the firm's profitability, thereby making it difficult to fit into GAAP's matching principle framework. The income against which loss carry-overs can be applied $(T I B L)$ has to be net of any lct paid. 
To derive an improved method of estimating taxable income, note that current tax expense for financial accounting purposes (CT expense) is a product of $s t r$ and the NIBT net of any $P D$ and $T D$.

$$
C T \text { expense }=\operatorname{str}[N I B T-P D-T D]
$$

The substitution of (5) into (2) gives:

$$
T I B L=\frac{\text { CTexpense }}{s t r}-1 c t
$$

Incidentally, Clinch and Shibano (p. 77) appear to estimate taxable income as federal taxes paid divided by the statutory tax rate. Unlike the U.S. environment, data on taxes paid is not publicly available for Canadian firms. In any case, Clinch and Shibano's estimate for TIBL will be overstated to the extent there are capital taxes paid.

Estimating taxable income based on equation (6) requires firm-specific financial statement footnote data on the statutory tax rate. This information is not available in any electronic database. Hence, this data would have to be manually collected from financial statements for all firm-years. The relevant Canadian financial statements are available from Micromedia Limited.

Step 2: The simulation of future $T I B L$ can be viewed as forecasts, which are based on the following algorithm:

$$
T I B L_{j, t+1}=\gamma_{j}+T I B L_{j t}+u_{j, t+1}
$$

Equation (7) can be restated as follows.

$$
\triangle T I B L_{j, t+1}=\gamma_{j}+u_{j, t+1}
$$

where $\gamma_{j}$ is a drift term (defined below) and $u_{j}$ are random numbers generated from a normal distribution with a mean zero and variance equal to the variance of the change in the historical TIBL series (i.e., $u_{j, t+1}$ $\left.\sim N\left(0, \sigma^{2}\left(\triangle T I B L_{j}\right)\right)\right)$. This simulation process uses random numbers rather than actual realizations to reflect management's uncertainty about future $T I B L$ at the time when the MTR is being estimated. Equation (8) reflects a stationary time series for $\triangle T I B L$, since its mean and variance do not change with time. The drift term $(\gamma)$ is equal to the mean change in $T I B L$ 
for each firm over the previous three years $\left(\triangle T I B L_{j}\right)$.

$$
\gamma_{j}=\frac{1}{3}\left[\sum_{t=2}^{0}\left(T I B L_{j t}-T I B L_{j, t-1}\right)\right]
$$

The estimation of $\gamma$ in equation (8) is identical to the OLS estimation of $\gamma$ from the following constrained regression:

$$
T I B L_{j t}=\gamma+1 T I B L_{j, t-1}+u_{t}
$$

where the coefficient on the independent variable is forced to be one. ${ }^{6}$

One problem with step 2 in the Canadian context is that unlike U.S. firms, Canadian firms have the choice of banking or stockpiling unused tax deductions for depreciation, resource write-offs, and other similar charges. Such unclaimed deductions can be carried forward indefinitely, and used to reduce tax liabilities in some future years. The magnitude of the impact of such unused deductions on current marginal tax rates is difficult to assess due to unavailability of longitudinal data. To the extent that firms decide to change the amount of deductions they are banking (e.g., start or stop banking), equation (7) will be in error because past behavior will no longer predict the future very accurately.

Step 3: Once the historical and simulated TIBL series is computed for each firm, the noncapital losses (if any) are applied sequentially to arrive at the taxable income (TI) series in the manner described below. This process is applied separately for each firm-year in which MTR is being estimated.

Manual collection of data is required for noncapital loss carryforwards, since convenient Compustat fields such as NOL Carry-forward (\#52) are coded as missing for all Canadian firms.

Although one cannot rule out the possibility that some firms with noncapital losses are not disclosing them, this seems unlikely since firms are not only required to disclose such losses under GAAP, but they would likely find it to their advantage to disclose such (hidden) assets

6. The proof that the last two expressions are identical is as follows: Let $y=T I B L_{t}-$ $T I B L_{t-1}$. Therefore, $y=\gamma+u$, Minimizing Sum of Squared Errors (MIN SSE) implies: MIN $\Sigma\left(y_{i}-\gamma\right)^{2}-2 \Sigma\left(y_{i}-\gamma\right)=0 ; \Rightarrow-2\left(\Sigma y_{i}-\gamma n\right)=0 ; \Rightarrow \Sigma y_{i}=n \gamma ; \Rightarrow \gamma=\Sigma y_{i} / n$. The first-order condition is $2 \Sigma\left(y_{i}-\gamma\right)(-1)=0, \Rightarrow \gamma=1 / n\left[\Sigma\left(T I B L_{t}-T I B L_{t-1}\right)\right]$. 
that can shelter future tax liability. ${ }^{7}$

The low incidence of loss disclosures may be partially explained by the fact that GAAP requires disclosure only if such noncapital losses are material. ${ }^{8}$ Firms wishing to extend the shelf-life of such tax deductions may "bank" their tax depreciation claims, thereby maintaining noncapital losses below the materiality threshold. ${ }^{9}$ A related disclosure issue in the Canadian context is that while noncapital losses may be immaterial on a consolidated basis, they may be significantly material for some specific corporate entities within the consolidated economic unit. Disclosures on loss carry-overs are not publicly available at the unconsolidated corporate entity level. Dhaliwal, Trezevant and Wang (1992, p.17) report that "many firms do not report the existence of $N O L$ carry-forwards in their financial statements until they are nearing expiration".

Canadian GAAP (CICA 3470.54) requires footnote disclosure of any material tax loss carry-forwards. The marginal tax rate estimates in this study are likely to be more reliable for firm-years that disclose positive loss carry-forwards than those that do not disclose zero or any other amount of losses. Hence, the marginal tax rate estimates may be potentially overstated for firms that may not have disclosed their loss carry-forwards for materiality or other strategic reasons.

If the initial balance of loss carry-forwards $(L C F D)$ is greater than zero, then the negation of that amount is deemed to be the initial year's $L C F D$, and hence the absolute value of that amount is the year's noncapital loss. If the $L C F D$ balance is not available from the footnotes or Compustat, then following Graham (1996a), Altshuler and Auerbach (1990) and Shevlin (1990), we assume that the LCFD is zero in 1985, and begin accumulating operating losses from 1985 onward. ${ }^{10}$ The algorithm then goes on to examine the next year in the firm's $T I B L$ series. If $T I B L<0$, then the noncapital loss for the year is equal to the

7. While the Ontario Securities Commission does not directly monitor GAAP compliance, its well-publicized lack of resources may induce audit firms (that monitor GAAP compliance) to reduce their audit scrutiny.

8. Graham (1999) also finds that Investment Tax Credits (ITCs) and Net Operating Losses (NOLs) in the U.S. Compustat are missing for many firm-years.

9. Noncapital losses can be carried forward for up to 7 years, while unused tax depreciation claims can be carried forward indefinitely.

10. Pre-1985 Compustat database has many more missing data of all types (not just losses) for Canadian firms. 
absolute value of $T I B L$. Making an assumption of this type is necessary since further steps in the algorithm require knowledge of when such noncapital losses will expire.

The algorithm imposes restrictions based on the implications of rational economic behavior. Rational economic behavior implies that all firms would choose receiving years and originating years in a certain pattern. First, all firms would wish to apply losses to the earliest possible years given the assumption of constant statutory tax rates over time. Canadian corporate statutory tax rates are flat, and not progressive. Furthermore, the period of investigation in this study was preceded by a period of higher statutory tax rates. This implies that firms would always want to exhaust carry back opportunities before using carryforward room. It also implies that all firms would prefer (if possible) to carry back losses to the earliest possible year, since the loss absorbing capacity of the early years expires first.

Second, if there is a choice in a given receiving year between absorbing losses of different originating years, then all firms would wish to choose the earliest originating year, since early losses have greater uncertainty of not offsetting future taxable profits. For example, if in period $t+1$ there is a choice between absorbing losses from year $t+2$ or year $t+3$, all firms would prefer to first absorb losses from year $t+$ 2 . The reason for such preference is that the latter losses have a longer remaining life before their 7-year expiration date.

The conditions described above are implemented in the algorithm in the following way. Losses (or negative TIBLs) are applied against positive TIBLs in the carry-over period in a chronological order, with the oldest originating losses being applied first. ${ }^{11}$ The carry-over periods for TIBL against which losses are applied are used as receiving years to soak up losses on a chronological (sequential) basis, starting with the earliest carry-over or receiving period first. After a receiving year's $T I B L$ is reduced to zero, any remaining losses (negative TIBLs) are applied against the next available year (in the carry-over period) with positive $T I B L$. This is continued until the earlier of (1) the time loss carry-overs are all exhausted, or (2) the time at which the carry-over range of actual and simulated $T I B L$ is used up (sequentially).

Once the loss carry-overs have all been applied, or the $T I B L$ series in

11. Carry-over period refers to both the carry-back ( 3 years) and the carry-forward (7 years) periods. 
the carry-over period has all been used up, the subsequent firm-year in which MTR needs to be estimated is examined. The loss carry-over applied in each year is limited to the lower of the loss carry-over amount and the positive $T I B L$ in that year. This ensures that the Taxable Income (TI) computed by deducting loss carry-overs from $T I B L$ does not become negative because of large loss carry-overs. Any loss applied in a given year reduces the loss carry-over balance by that amount. Any amount carried over and deducted from $T I B L$ of another year is also added to the $T I B L$ of the originating year, thereby reducing the loss (or negative $T I B L)$ in the originating year.

The amount remaining after loss carry-overs have been deducted from $T I B L$ is considered the taxable income ( $T I)$ for that firm-year. This process is repeated sequentially to derive the taxable income $(T I)$ for each firm-year for which $T I B L$ is available.

One problem with the above algorithm is that it neglects multi-year effects. To understand the nature of the problem, consider the following two scenarios, which are based on 2004 as the current year, and 44.8 percent as the statutory marginal tax rate for all years.

Example: 2004 taxable income and tax liability are positive, but (at least) one of the three subsequent years (say 2007) has a noncapital loss that is (at least, partially) carried back to 2004, resulting in a refund of (at least some) 2004 taxes paid in that future year.

A \$1 increase in 2004 income may produce at least 3 separate effects. First, the 2004 tax liability increases by $\$ 1 \times s_{2004}=\$ 0.448 .{ }^{12}$ Second, the $\$ 1$ of incremental income will also increase the loss absorption capacity of 2004 by $\$ 1$. This may allow $\$ 1$ of additional losses from the three subsequent years to be carried back and deducted in the 2004 taxation year. The loss carry-over deduction is limited to the lower of the noncapital loss amount and the taxable income in the period in which the carry-over amount is deducted. Hence this second effect will only occur in situations where the taxable incomes of the immediately prior three years (to 2004) are not sufficient to absorb all of the noncapital loss carry-backs. \$1 of additional 2004 loss absorption capacity may allow $\$ 1$ more of 2007 noncapital losses to be deductible in the 2004 taxation year, thereby producing a tax refund of \$1 x str ${ }_{2004}$ in 2007.

However, the use or absorption of an additional \$1 of 2007 noncapital losses (against 2004 taxable income) can create a potential

12. Future noncapital losses are not deductible, since they are speculative in nature. 
third effect. Loss carry-overs should be viewed as assets to the extent that they can shelter income that would otherwise be taxable, thereby producing cash savings (or reducing cash outflows). Using up such an asset in 2004 means that it is not available for use (in sheltering income against taxes) in the 7-year (carry-forward) period beyond 2007. Income (of year 2009, for example) that could have been otherwise sheltered in this 7-year period could now be taxable at that future year's statutory marginal tax rate.

This third effect exists only if the loss carry-overs are expected not to be used within the allowable carry-over period, and expire unused. Use of loss carry-overs signifies net future cash inflows to the firm, thereby enabling loss carry-overs to fit the definition of an asset. The above three effects can be combined to derive the current year's (2004) effective marginal tax rate as:

$$
0.448-\frac{0.448}{(1+r)^{3}}+\frac{0.448}{(1+r)^{5}}
$$

which, if $r=10$ percent, is $38.9 \%$.

It is also possible that this process will not stop in the year 2007. Suppose in the year 2009, there is a large noncapital loss that can be carried back to reduce taxable income in the year 2007 to zero. This noncapital loss would otherwise have been used in the year 2016. This adds the following two extra terms to the MTR calculation above.

$$
\frac{-0.448}{(1+r)^{8}} \text { and } \frac{+0.448}{(1+r)^{12}}
$$

This process of tracing effects through future years could possibly continue indefinitely into the future. As pointed out by Shevlin (1990, footnote 5), extending the simulation beyond $t+3$ adds very small amounts to the estimated rates, largely because of discounting.

Step 4: Multiplying the $T I$ by the firm-specific statutory tax rates computes taxes payable for each firm-year. Firm-years with negative taxable income are deemed to have zero taxes payable. This occurs whenever there is no sufficient positive $T I B L$ in the carry-over (receiving) period to soak up the originating negative TIBL. Setting taxes payable to zero in such cases is consistent with the asymmetric treatment 
of losses under the Canadian Income Tax Act, under which refunds are not available for $T I<0$.

The taxes payable $(T P)$ for each year are then discounted (at an arbitrary after-tax rate of 10 percent) to the MTR estimation year in order to determine the present value of income taxes payable. ${ }^{13,14}$

Once the present value of taxes payable in the MTR estimation year has been computed, the entire algorithm is repeated after adding $\$ 1$ to the TIBL in the estimation year. Losses are carried back and forward once again on a sequential basis, starting with the oldest originating losses and the earliest receiving periods within the carry-over range. A new taxable income series $\left(T I^{\prime}\right)$ is determined, and new taxes payable $\left(T P^{\prime}\right)$ computed by multiplying this new $T I$ series with the firm-year specific statutory tax rates. These new taxes payable are then discounted (at the same after-tax rate of 10 percent) back to the MTR estimation year to determine the $P V$ of the revised income taxes payable. Following Shevlin (1990), the difference between the two present value amounts ( $P V$ of $T P^{\prime}$ minus $P V$ of $T P$ ) constitutes the marginal tax rate estimate for that particular firm-year.

Once a marginal tax rate estimate $(M T R)$ has been obtained for a firm-year, the $T I B L$ series is simulated (or projected) once again for the 7-year carry-forward period beyond the last estimation year using a new series of random numbers generated from the normal distribution $N(0$, $\left.\sigma^{2}(\triangle T I B L)\right)$. The drift term $(\delta)$ remains the same for all simulations for the same estimation year.

This simulation step is repeated 50 times with a new series of random numbers for the error term $\left(u_{j t}\right)$ each time. The 50 different estimates for each firm-year's marginal tax rate are then averaged to arrive at the mean firm-year marginal tax rate $(t)$ as described in the following expression:

$$
\tau=\frac{1}{50} \sum_{i=1}^{50} m t r_{j i}
$$

13. Interest on funds borrowed to pay income taxes is not deductible for tax purposes. However, most firms are likely to deduct such amounts since it is difficult to disentangle funds borrowed to earn regular business income from funds borrowed to make income tax payments.

14. Shevlin (1990) uses the after-tax discount rates obtained from the All Industries Corporate Bonds: Seasoned Issues. He argues against using variations in risk premiums across firms on the grounds that the risk premium may be correlated with the financial condition of the firm, which, in turn, may be correlated with marginal tax rates. He finds that his simulation results are not sensitive to variations in this discount rate from 5 to 10 percent. 


\section{Canadian versus U.S. Differences}

One problem with step 4 in the Canadian context concerns Canadian firms that are subsidiaries of foreign-based corporations. To the extent that a reduction of Canadian income taxes reduces the foreign tax credit $(F T C)$ for the foreign-based parent of the Canadian subsidiary on a dollar-for-dollar basis, there is no net tax savings for the entity at the consolidated level. This would be the case if the parent of the Canadian subsidiary is in a jurisdiction that taxes worldwide income of their resident companies (e.g., U.S.A., U.K., and Japan). The foreign tax credits are designed to avoid multiple taxation of income, although they do not always accomplish this objective because of FTC limitations and differing definitions of taxable income across taxing jurisdictions (Scholes and Wolfson [1992], p. 246). Multiple taxation may also not be entirely avoidable if incentive and control mechanisms instituted in the Canadian subsidiary reward Canadian management based on the subsidiary's after-tax net income rather than the parent's consolidated bottom line.

Resolving this $F T C$ issue requires identifying parent companies (of Canadian firms for which MTR needs to be estimated) and their jurisdiction. Financial statement footnotes of such parent companies would then need to be examined for FTCs related to Canadian income taxes. Canadian companies whose foreign parents have such FTCs would have less of an incentive to undertake tax-reducing strategies. ${ }^{15}$ However, Canadian subsidiaries with foreign parents that do not have FTC s continue to have incentives to undertake tax reducing strategies via means such as debt shifting, as documented by Hogg and Mintz (1991) and Jog and Tang (1997).

One way to capture this disincentive is by subtracting the loss of the parent's FTC from the Canadian subsidiary's net tax benefits of the marginal tax-reducing strategy being considered. Alternatively, such firms can be eliminated from the sample, particularly if the parent company's disclosure does not have sufficient (e.g., country-specific) detail. This issue adds noise to the empirical results since foreign subsidiaries in this sample are not identifiable due to the lack of publicly available ownership data on Canadian corporations.

15. In the U.S. context, Collins, Kemsley and Lang (1998) use average tax rates to capture FTC limitations at the margin on the grounds that the FTC limitation is based on aggregate foreign taxes paid rather than on a country-by-country basis, and the credit includes all foreign income taxes. 
A second problem with step 4 is that Canadian firms are required to file tax returns on a legal entity basis as opposed to a consolidated basis. This accentuates the difference between a firm's current tax expense reported in the financial statements, and its current tax liability reported on its tax return. ${ }^{16}$ While differences in rules between financial consolidation and tax consolidation exist in the U.S., they are not as divergent as the Canadian differences. ${ }^{17}$ Each legal entity within the consolidated firm may have a separate statutory and effective tax rate, as well as its own pool of loss carry-forwards and unused bank of tax deductions. Due to unavailability of both accounting and tax data at the legal entity level, this study can only estimate or measure consolidated marginal tax rates based on the usage of consolidated NOL carryforwards. The extent of "noise" in the estimated measures will be directly related to the extent of restrictions (tax and otherwise) that firms face in transferring loss carry-forward pools and unused tax deduction banks between legal entities within the consolidated shell.

This "noise" will be small to the extent that firms can transfer losses between related companies. ${ }^{18}$ While the Income Tax Act does not allow a strict transfer of losses between related corporations, Section 85 makes it perfectly legal to transfer income (or loss)-producing assets from one related company to another. In most cases, this rollover or transfer of assets between related companies can be done with no immediate tax consequences. Hence, a group of corporations with uneven distribution of income and losses has significant incentives to carry out such rollovers barring non-tax costs. Furthermore, these asset rollover provisions have existed for a long time, thus allowing firms to be entirely familiar with them. In addition, the tax authority is not attempting to restrain firms from undertaking such inter-company asset transfers. Therefore, firms can be expected to implement such widely known tax planning measures in a timely manner to maximize the present value of

16. All financial statement measures of tax rate suffer from measurement error to the extent that financial and tax reporting is different and unreconcilable. Plesko (1999) provides an overview of the differences between tax and financial reporting

17. In the U.S., "inclusion of subsidiaries in consolidated financial statements of the parent company requires greater than 50\% ownership while inclusion of subsidiaries in consolidated income tax returns requires greater than $80 \%$ ownership" (Callihan, 1994, p. 16). This difference in rules contributes "noise" to the marginal tax rate estimates in studies such as Shevlin (1990) and Matsunaga, Shevlin and Shores (1992).

18. Department of Finance, Canada (1985a) surveys various means by which losses can be transferred between related corporations. 


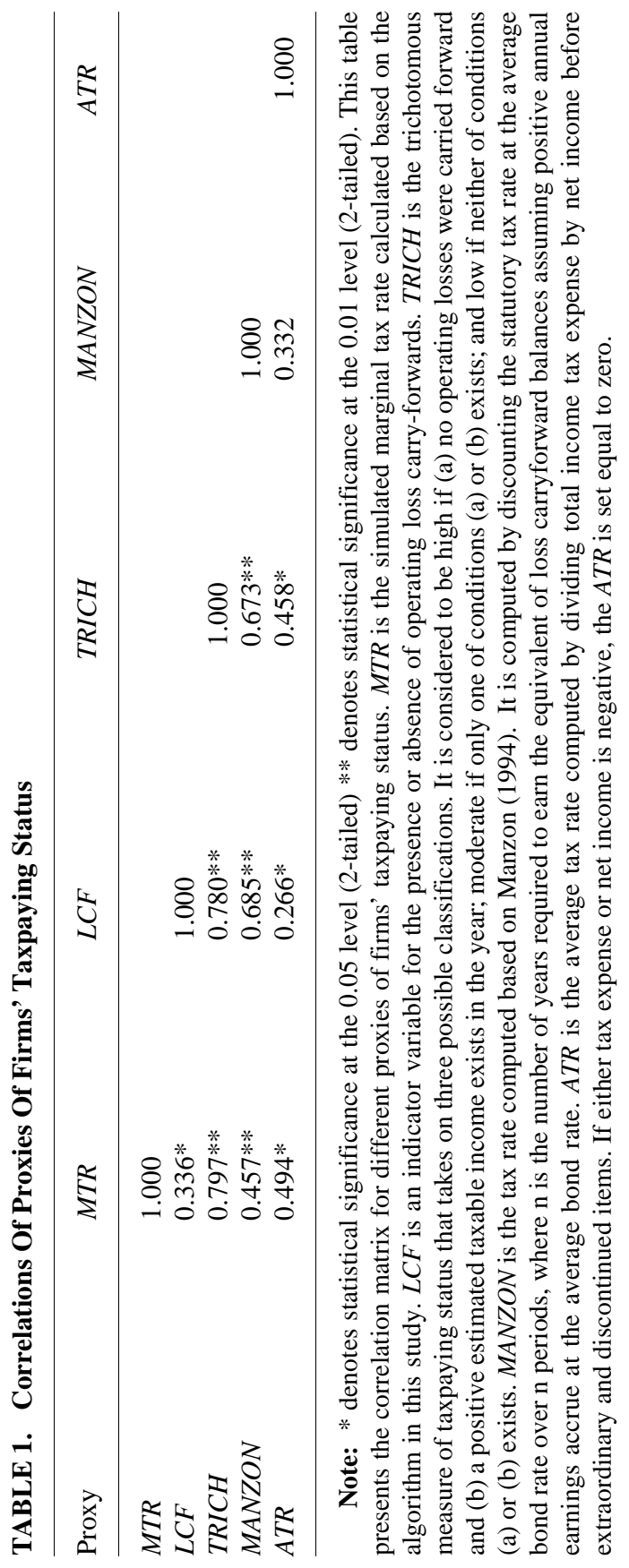


their tax savings.

Other means to alter the distribution of income and losses within a corporate group include inter-company debt (at market rates), inter-company charges for rent, management fees and other similar items that allow individual corporations within the group to better match their available deductions against specific sources of income that would otherwise be taxable. Hence, inability to file consolidated tax returns may not be as crucial in the context of these other provisions. The flexibility inherent in other provisions of the Income Tax Act may allow related companies to rearrange their affairs in a way that achieves results that approximate those obtained under strict consolidated tax returns.

\section{Comparison to Other Proxies}

This data-intensive algorithm would be of limited application if the resulting simulated marginal tax rates were highly correlated to simple measures or proxies of firms' taxpaying status. Other proxies for firms' taxpaying status used in the literature include an indicator variable for loss carry-forwards (LOSS), a trichotomous variable described in Graham (1996a) (TRICH), Manzon's measure (MANZON) described in Manzon (1994), average tax rates $(A V G)$, and statutory tax rates $(S T R)$. Table 1 presents the correlations between these commonly used proxies for firms' taxpaying status. It illustrates that while some of the proxies are significantly correlated to the simulated marginal tax rate developed in this study, many of them are not significantly correlated. Using the more simple and easier to access measures for a firm's taxpaying status to proxy for the theoretically sound marginal tax rate can result in biased and inefficient estimators because of the spurious increase in both Type I and Type II errors.

The measurement benefits of the marginal tax rate are dampened by lack of publicly available input data. For example, the lack of public disclosure on losses can significantly reduce the variation in the estimated marginal tax rates, even though the simulation process allows for much greater variation. However, the marginal tax rate could be easily computed by managers inside a firm based on data inside the firm, since there would not be any information constraint. Such a measure would greatly enhance planning inside a firm. Major multinationals generally calculate such marginal tax rates for each of their subsidiary, and require they be used for planning decisions such as pricing. 


\section{Conclusion}

This study examined the theoretical considerations and empirical implications for measuring corporate marginal tax rates in the Canadian context. Among the firm characteristics that influence marginal tax rates, the most prominent is noncapital losses. The study illustrated the complexity of calculating corporate marginal tax rates in the presence of noncapital losses. Actual and simulated noncapital losses were carried back and forward to estimate projected taxable income according to the Canadian tax legislation. Various tax provisions such as the requirement to file unconsolidated tax returns and the choice of banking unused tax depreciation claims introduce measurement error in estimating corporate marginal tax rates from publicly available data. In addition, inadequate disclosure of noncapital losses in financial statement footnotes may also impede the starting point of the marginal tax rate estimation process.

This study contributes to the literature by developing an algorithm for simulated marginal tax rates based on Canadian tax law. Using an inappropriate measure of a firm's taxpaying status to proxy for the marginal tax rate can result in biased and inefficient estimators because of the spurious increase in both Type I and Type II errors. Lack of disclosure or absence of noncapital losses reduces the variation in estimated marginal tax rates, even though the simulation methodology allows greater variation based on the variance of each firm's change in taxable income. If such disclosure is inadequate, then further research into why firms may hesitate to make such disclosures could yield interesting insights. ${ }^{19}$ The robustness of the corporate marginal tax rates estimated in this study also depend critically on (1) the quality of the financial statement data for the initial stock of noncapital loss carryforwards and for the relatively uniform disclosure of permanent differences; (2) the assumption regarding the future taxable income or loss generating process; and (3) the choice of (after-tax) discount rate. Future research could examine the impact of different data and process assumptions on the estimated marginal tax rates.

19. Canadian Financial Reporting Principles allows recognition of tax (losses) recoverable on the balance sheet if firms can demonstrate "virtual certainty" of earning sufficient positive taxable income in the carry-forward period. In most cases, this stringent "virtual certainty" test is not met. Firms may be reluctant to disclose loss carry-forwards in the footnotes if they perceive that the users may judge them harshly for not being virtually certain about utilizing the losses. Auditors would insist on footnote disclosure only if such losses were material or about to expire. CICA 3465 allows recognition of tax loss recoverable if such loss amounts are "more likely than not to be realized." This will constitute a much less stringent requirement than "virtual certainty." 


\section{References}

Altshuler, R., and Auerbach, A. 1990. The significance of tax law asymmetries: An empirical investigation. Quarterly Journal of Economics CV, 61-86.

Archambault, J., and Archambault, M. 1994. Inventory accounting policy choice among Canadian firms. Journal of International Accounting, Auditing and Taxation 3(2):153-167.

Boatsman, J., and Gupta, S. 1996. Taxes and corporate charity: empirical evidence from micro-level panel data. National Tax Journal Vol. XLIX, No.2:193-213.

Callihan, D. 1994. Corporate effective tax rates: A synthesis of the literature. Journal of Accounting Literature Vol. 13, pp. 1-43.

Canadian Institute of Chartered Accountants, CICA Handbook

Clinch, G., and Shibano, T. 1996. Differential tax benefits and the pension reversion decision. Journal of Accounting and Economics Vol. 21, No.1, (1996): 69-106.

Chevreau, J. 1998. Corporate tax overhaul would affect personal taxation report. The Financial Post April 18.

Collins, J.; Kemsley, D.; and Lang, M. 1998. Cross-jurisdictional income shifting and earnings valuation. Journal of Accounting Research Vol. 36, No.2 (Autumn):209-229.

Cordes, J., and Sheffrin, S. 1983 Estimating the tax advantage of corporate debt. Journal of Finance 38:95-105.

Day, K. M., and Devlin, R. M. 1994. An empirical analysis of corporate giving in Canada. Working Paper, University of Ottawa.

DeAngelo, H., and Masulis, R. 1980. Optimal capital structure under corporate and personal taxation. Journal of Financial Economics 1 (March): 3-29.

Department of Finance, Canada. 1985a. A Corporate Loss Transfer System for Canada Ottawa.

Department of Finance, Canada. 1985b. The Corporate Income Tax System: A Direction for Change Ottawa.

Department of Finance, Canada. 1994. Government of Canada Tax Expenditures Ottawa.

Dhaliwal, D.; Trezevant, R.; and Wang, S. 1992. Taxes, investment-related tax shields and capital structure. The Journal of the American Taxation Association Vol. 14, No. 1 (Spring):1-21.

Erickson, M. 1998 The effect of taxes on the structure of corporate acquisitions. Journal of Accounting Research Vol. 36, No.2 (Autumn):279-298.

Glenday, G., and Mintz, J. 1991. The nature and magnitude of tax losses of Canadian corporations. Chapter 2. In Policy Options for the Treatment of Tax Losses in Canada The Clarkson Gordon Foundation, Toronto.

Gouvernement du Québec Ministère des Finances. 1997. Corporate Tax Statistics for Taxation Year 1992. News Release, Quebec City, November 28. 
Graham, J. R. 1996a. Proxies for the corporate marginal tax rate. Journal of Financial Economics 42:187-221

Graham, J. R. 1996b. Debt and the marginal tax rate. Journal of Financial Economics 41:41-73.

Graham, J. R. 2000. How big are the tax benefits of debt? Journal of Finance. Vol 55, 1901-1941.

Graham, J. R., and Smith, C. 1999. Tax incentives to hedge. Journal of Finance Vol. 54, no. 6: 2241-2262.

Graham, J. R.; Lemmon, M.; and Schallheim, J. 1998. An empirical investigation of debt, leases, and taxes. Journal of Finance 53, 131-161.

Hayn, C. 1995. The information content of losses. Journal of Accounting and Economics Vol.20, No.2:125-153.

Hogg, R. D., and Mintz, J. M. 1991. Canadian and U.S. tax reform impacts on the financing of Canadian subsidiaries of U.S. parents, Conference on International Aspects of Taxation, National Bureau of Economic Research, New York, September 26-28.

Holland, D., and Castonguay, A. 1992. The corporate income tax: preliminary results on the impact of tax reform. 1991 Conference Report Canadian Tax Foundation Toronto 201-18.

Jog, V., and Tang, J. 1997. Tax reforms, debt shifting and corporate tax revenues: Multinational corporations in Canada. Technical Committee on Business Taxation, Paper 1997-14.

Klassen, K., and Mawani, A. 2000. The impact of financial and tax reporting incentives on option grants to Canadian CEOs. Contemporary Accounting Research Vol 17, No. 2: 227-262.

MacKie-Mason, J. K. 1990. Do taxes affect corporate financing decisions? Journal of Finance 45:1471-1493.

Manzon, G. 1994. The role of taxes in early debt retirement. The Journal of the American Taxation Association Vol. 16, No. 1 (Spring): 87-100.

Matsunaga, S.; Shevlin, T.; and Shores, D. 1992. Disqualifying dispositions of incentive stock options: Tax benefits vs. financial reporting costs. Journal of Accounting Research Vol. 30, p.37-68.

Mawani, A. 2003. Cancellation of executive stock options: Tax and accounting income considerations. Contemporary Accounting Research Vol. 20, No. 3 (Fall): 495-517.

McKenzie, K. J.; Mansour, M.; and Brule, A. 1998. The calculation of marginal effective tax rates. Working Paper 97-15, Technical Committee on Business Taxation.

Milevsky, M. A., and Prisman, E.Z. 1997. Tax effects in Canadian equity option markets. Multinational Finance Journal Vol. 1, no. 2, pp. 101-122.

Mintz, J. 1988. An empirical estimate of corporate tax refundability and effective tax rates. The Quarterly Journal of Economics p. 225-231.

Mintz, J. 1991. Economic implications of non-refundability of tax losses. Chapter 4. In Policy Options for the Treatment of Tax Losses in Canada 
Clarkson Gordon Foundation, Toronto.

Modigliani, F., and Miller, M. H. 1963. Corporate income taxes and the cost of capital: A correction. American Economic Review 53: 433-443.

Omer, T.; Molloy, K.; and Ziebart, D. 1991. The measurement of effective corporate tax rates using financial statement information. Journal of the American Taxation Association Vol. 13, No. 1 (Spring):57-72.

Plesko, G.A. 2003. An evaluation of alternative measures of corporate tax rates. Journal of Accounting and Economics Vol. 35, No. 2:201-226.

Department of Finance, 1998. Report of the Technical Committee on Business Taxation Ottawa, Canada.

Scholes, M., and Wolfson, M. 1992. Taxes and Business Strategy: A Planning Approach Prentice-Hall, Englewood Cliffs, NJ.

Shanker, L. 1997. Tax effects and the leasing decisions of Canadian corporations. Canadian Journal of Administrative Sciences 14(2):195-205.

Shevlin, T. 1987. Taxes and off-balance sheet financing: Research and development limited partnerships. The Accounting Review Vol. LXII, No. 3, pp. 480-509.

Shevlin, T. 1990. Estimating corporate marginal tax rates with asymmetric tax treatment of gains and losses. Journal of American Taxation Association Vol. 11, No. 2, p. 51-67.

Shum, P. 1996. Taxes and corporate debt policy in Canada: An empirical investigation. Canadian Journal of Economics August:556-72.

Statistics Canada 1997. Financial and Taxation Statistics for Enterprises 1995 (cat. no. 61-219-XPB, March).

Statistiques fiscales des sociétés: Année d'Imposition 1992, Édition 1997 (Québec: Publications de Québec)

Warsame, H., and Thornton, D. 1998. Interaction of tax planning and financial reporting: Reaction of Canadian corporations to the taxation of preferred dividends. Working Paper, Queen's University.

Zimmerman, J. L. 1983. Taxes and firm size. Journal of Accounting and Economics 5:119-149 